\title{
Ectoparasites (Insecta and Acari) Associated with Bats in South and South-Western Caves of Iran
}

\author{
Mohammad Javad Malek-Hosseini ${ }^{1,2}$, \\ Saber Sadeghi* ${ }^{1}$, Yaser Bakhshi', \\ Meysam Dashan ${ }^{1}$ \\ ${ }^{1}$ Department of Biology, Faculty of Science, Shiraz \\ University, Shiraz, IRAN. \\ ${ }^{2}$ Evolutionary Zoology Laboratory, Biological \\ InstituteZRC SAZU, Ljubljana, Slovenia
}

Study Area: Kohgiluyeh \& Boyer-Ahmad province \& Fars Province, Iran Coordinates: $27032^{\prime} 44^{\prime \prime} \mathrm{N}, 55020^{\prime} 21^{\prime \prime}$ to $31^{\circ} 17^{\prime} 96^{\prime \prime}$ N, $50^{\circ} 35^{\prime} 13^{\prime \prime} \mathrm{E}$

Key words: Cavernicoles, Cave bats, Zagros Mountains.

\section{Abstract}

This paper presents a part of the study conducted on cave fauna in Kohgiluyeh \& Boyer-Ahmad and Fars provinces, South West and South of Iran. Eleven caves were investigated and seven species of bats were examined for identifying the ectoparasites. We found six species of ticks (Acari: Ixodidae) and four mites (Acari: Spinturnicidae and Macronyssidae), eight species of Nycteribiidae and two Strelibidae (Diptera: Insecta) as ectoparasites of bats. Two species of ticks and mites; Ixodes simplex (Ixodidae) and Macronyssus granulosus (Macronyssidae) were recorded for the first time from Iran. The threats from such ectoparasites have been discussed.

\section{Introduction}

Zagros is a mountain range that extends from Turkey, Iraq to Iran, which is oriented from the northwest to the south Iran, and comprising nearly one fifth of the surface area of the country. Zagros, Elburz and central mountainous regions of Iran are mainly the karstic landscapes (Ghaderi \& Karimi, 2014; Malek Hosseini et al., 2015a). This region harbors many caves, till date many of which remain unexplored. All such caves which have been surveyed for bioinventory works in the present study are located in the central and southern parts of the Zagros Mountains.

Microchiropteran bats are the major and most common biotic component for most of the caves. The ectoparasites in bats which includes ticks, mites, fleas, flies, bugs, and lice cause illness and reduced fecundity in bats (Krasnov et al., 2004). 
The body structure of the ectoparasites mostly depends on their host species, environments, bionomics, and habitat (Haitlinger \& Łupicki, 2008). The most conspicuous bat ectoparasites are the bloodsucking Nycteribiid and Streblid flies, (Marshall, 1982). Some families of the ectoparasites have obligatory hematophagous species that only limited to bats (Krantz \& Walter, 2009).

The presnt piece of work is an attempt to improve our knowledge regarding the ectoparasites associated with the microchiropteran bats abiding in the central Zagros caves.

\section{Material and Methods::}

Study sites: In the present study we targeted seven subterranean caves of Zagros mountain off icially exist in two provinces.

A: Kohgiluyeh \& Boyer-Ahmad province: four following caves were visited in Kohgiluyeh \& Boyer-Ahmad province (an uneven and mountainous province at the middle of Zagros Mountain, south-west of Iran), in different months of the year.

i) Deh Sheikh (Pataveh) Cave, in the mountains that surround Deh Sheikh village, North West of Yasuj, (30 $57^{\prime} 22^{\prime \prime} \mathrm{N}, 5^{\circ}{ }^{\circ} 14^{\prime} 17^{\prime \prime}$ E, 1735 ma. s. 1., Sep. 27, 2011).

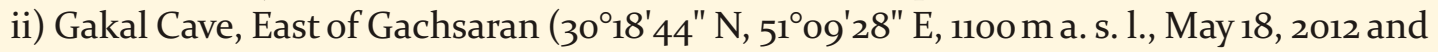
Oct. 2, 2012).

iii) Kiler Cave, in the northwest of Yasuj ( $31^{\circ} 17^{\prime} 96^{\prime \prime} \mathrm{N}, 50^{\circ} 35^{\prime} 13^{\prime \prime}$ E, 1610 m a. s. 1., Oct. 27, 2011 and 11 July 2012).

iv) Neyneh Cave, in the southwest of Dehdasht $\left(30^{\circ} 40^{\prime} 18^{\prime \prime} \mathrm{N}, 50^{\circ} 21^{\prime} 71^{\prime \prime} \mathrm{E}, 770 \mathrm{~m}\right.$ a. s. 1., May 17, 2012).

B: Fars Province: three caves in Fars province (south of Iran) were visited in different times of theyear:

v) Shafagh Cave, about $75 \mathrm{~km}$ north-west of Jahrom city in Fars province ( 280 40' 8" N, 520 56' 34" E, 1506 ma. s. 1., in July. 6, and Dec. 8, 2013).

vi) Tadovan Cave, Khafr Jahrom road (280 50' 48" N, 530 19' 46" E, 1200 ma. S. L., Oct. 7, 2013).

vii) Charkhab Cave, south of Fars province. This cave is located in the Hormood protected area (270 32' 44" N, 550 20' 21" E. Altitude 639m., Dec. 30, 2013).

Bats and ectoparasites sampling: The bats were captured using an aerial net and then anesthetized with chloroform at the same place. After collecting the ectoparasites we released each bat in normal sense conditions. However, one specimen of each bat species was transferred to the laboratory for precise identification.

The host bats were precisely searched for ectoparasites and then both bats as well as their parasites were preserved in $75 \%$ ethanol. The isolated mites were prepared in $15 \% \mathrm{KOH}$ solution and stored in "Liquido de Swan" then processed for permanent slide preparation according to Ref. The bat flies (Nycteribiidae and Strelibidae) were identified under stereo microscope using taxonomical keys including Theodor \& Mosconam (1954) and Theodor (1967). The voucher parasite specimens of each species were deposited in Zoology Museum of 
Biology Department in Shiraz University (ZM-CBSU), and also in personal collection of the Dr. Martin Ševčík, from Charles University in Prague (Faculty of Science, Department of Zoology).

The taxa were arranged alphabetically and species data were represented in the following format: synonyms, published data, and material examined (number of specimens, locality, date, and number of host, previous records, and distribution).

\section{Results and Discussion:}

Ectoparasites: two families of mites (Macronyssidae and Spinturnicidae), one family of ticks (Ixodidae) and two families of insects (Nycteribiidae and Strelibidae) were collected from the bats belonging to the families of Rhinopomatidae, Rhinolophidae, Vespertilionidae, and Pteropodidae found in seven caves of the studied area.

Family: Nycteribiidae Samouelle, 1819

Nycteribia latreillii (Leach, 1817)

Material examined: 20 from 1 ind. Miniopterus schreibersii, Oct. 27, 2011; 19 from 1 ind. Miniopterus schreibersii, July. 11, 2012, local. [3]; 20 from 1 ind. Myotis sp., May. 17, 2012, [4]; 19 from 1 ind. Myotis blythii, May. 18, 2012, local. [2].

Previous records from Iran: Bazangan (Khorasan-e Razawi Province.)(Benda et al., 2012)

Distribution: Europe, Asia, North Africa.

Nycteribia pedicularia Latreille, 1805

New records: 20, 2 female from 1 inds. Rhinopoma muscatellum, May. 17, 2012, local. [4]. 7 specimens from 6 inds. Miniopterus schreibersii (4 Oand 3), 6 July, local. [5].

Previous records: Fars Province (Maa, 1968; Kock, 1983).

Distribution: Europe, Asia- Turkey, Israel, Iran; North Africa, Tunisia, Algeria.

Nycteribia schmidlii Schiner, 1853

New records: 5 व 29 from 1 ind. Miniopterus schreibersii, Oct. 27, 2011, local. [3]; 2ofrom 1 ind. Myotis blythii, July. 11, 2012, local. [4]. 1ఠ, May. 18, 2012) local [2], from 1 ind. Myotis blythii and (20, 1 $:$ : Oct. 2, 2012) from 1 ind Miniopterus schreibersii, local [2]

(1 9 : May. 17, 2012) local [4], host: 1 ind Myotis sp.; 3 б, 3 \& from 5 inds. Miniopterus schreibersii, Nov. 7, 2013, local [6]. ; 1 \& from 6 inds. Miniopterus schreibersii, July. 6, 2013, local. [5]. 5 o, 2 \& from 3 inds. Miniopterus schreibersii, Dec. 8, 2013, local [5].

Previous records: Mozduran Cave, Khorassan [Khorasan-e Razawi Province] (Kock, 1983), North of Iran (Hůrka, 1984), Tadovan cave (Fars Province),(Benda et al., 2012).

Distribution: Europe; Asia, North Africa.

Nycteribia vexata Westwood, 1835

Previous records: Alborz Mts. (Maa, 1968) North of Iran (Kock, 1983). Alburz Mountains (Theodor, 1967),

New records: 10,19, from 1 ind. Myotis blythii, May. 18, 2012, local [2].

Distribution: Europe, Asia, North Africa.

Penicillidia conspicua Speiser, 1901

New records: 1ơfrom 1 ind. Miniopterus schreibersii, Oct. 27, 2011, local [3]. 1 ofrom 5 inds. Miniopterus schreibersii, Nov. 7, 2013, local [6]

Previous records: North of Iran (Kock, 1983), Tadovan cave (Fars Province), Dashkasan, Dashkahul cave (Ardabil Province), Mozduran Cave, Khorassan [Khorasan-e Razawi Province] (Benda et al., 2012)

Distribution: Europe, Asia, North Africa.

Penicillidia dufourii (Westwood, 1835)

New records: 2б, 1 오 from 1 ind. Myotis blythii, Oct. 27, 2011, local [3]; 1 9from 1 ind. Myotis blythii, May. 18, 
2012, local [2]; 1 \&, from 1 ind. Myotis sp., May. 17, 2012, Local [4]; 20, 19 from 6 inds. Miniopterus schreibersii, July. 6, 2013, local [5].

Previous records: Alborz Mts (Theodor, 1967), North of Iran (Kock, 1983), (Benda et al., 2012)

Distribution: Europe, Asia- India, North Africa.

Eucampsipoda hyrtlii Kolenati, 1856

New records: 1 from 1 ind. Rousettus aegyptiacus, July. 6, 2013, local [5].

Previous records: North of Iran (Kock, 1983), Kuhhaye Genu Mts (Hormozgan province) (Hůrka, 1984) .

Distribution: Europe and the Mediterranean region, Asia -Iran.

Phthiridium biarticulatum Hermann, 1804

New records: 20 from 14 inds. Rhinopoma muscatellum, Jan. 9, 2014, local [7]. 19 from 2 inds. Rhinolophus hipposideros, Nov. 7, 2013, local [6]. 20, 2 \& from 7 inds Rhinopoma muscatellum, Nov. 7, 2013, local [6].

Previous records: North of Iran, Mozduran Cave, Khorassan [Khorasan-e Razawi Province] (Kock, 1983), Dashkasan, Dashkasan cave (Ardabil Province) (Benda et al., 2012)

Distribution: Circum-Mediterranean and reaches Tajikistan and Kyrgyzstan.

\section{Family: Strelibidae Kolenati, 1863}

Brachytarsina alluaudi minor Falcoz, 1923

New records: 5 \%, 8 \% from 14 inds Rhinopoma muscatellum, Jan. 9, 2014, local [7].

Previous records: Estahbanat (Fars Province) (Maa,1968)

Distribution: Mediterranean zone, Middle East Africa, Afghanistan.

Brachytarsina flavipennis Macquart 1851

New records: 1 from 2 inds. Rhinolophus hipposideros, Nov. 7, 2013, local [6]

Previous records: North of Iran , Mozduran Cave, Khorassan [Khorasan-e Razawi Province], (Kock, 1983),

Tadovan cave (Fars Province), Meymand (Kohgiluyeva Boyer Ahmad Province), (Benda et al., 2012).

Distribution: Mediterranean zone, Middle East Africa, Afghanistan.

\section{Order: Ixodida Leach, 1815}

Family: Ixodidae Koch, 1844

Ixodes simplex Neumann, 1906

New records: 1 nymph from 1 ind. Miniopterus schreibersii, Oct. 27, 2011, local [3].; 2 larvae from 5 inds. Miniopterus schreibersii, Nov. 7, 2013, local [6].

Distribution: Europe, Asia, Africa, New Guinea, Australia. Distribution of this species is also reported from the Palaearctic, Afrotropical, Oriental and Australian regions.

Remarks: New for fauna of Iran.

Ixodes vespertilionis Koch, 1844

New records: 1 larva from 1 ind. Rhinolophus hipposideros, sep. 27, 2011, local [1]. 1 larvae from 7 inds. Rhinopoma muscatellum, Nov. 7, 2013, local [6].

Previous records: North of Iran (Pomerantzev, 1959), Kermanshah province (Vatandoost et al., 2010), Meymand (Kohgiluyeva Boyer Ahmad Province) (Benda et al., 2012).

Distribution:Europe, Africa, Middle East and Southeast Asia, Pacific Islands, China and Japan.

\section{Order: Mesostigmata}

Family: Spinturnicidae Oudemans, 1902

Spinturnix myoti (Kolenati, 1856)

New records: 10 , from 1 ind. Myotis blythii, July. 11, 2012, local [3], 10 , 1 ९, from 1 ind. Myotis blythii, May. 18, 2012, local [2].

Previous records: Ali Abad (Golestan Prov.), Tadovan, Tadovan cave (Fars Prov.), (Benda et al., 2012).

Distribution:Turkey, Transcaucasia, and West Turkestan.

Spinturnix psi (Kolenati, 1856)

New records: 20, 2 \& from 3 inds. Miniopterus schreibersii, Oct. 27, 2011, local

[3]; 1 б, 1 female from 1 ind. Myotis blythii, July. 11, 2012, local [3]; (1 9 from 1 ind Rhinopoma microphyllum, Oct. 
2, 2012, local [2], 10 from 6 inds. Miniopterus schreibersii, July. 6, 2013, local [5].30, 1 우 1 nymphal stage from 3 inds. Miniopterus schreibersii, Dec. 8, 2013, local [5].

Previous records: Tadovan cave and Hesar (Fars Province), Mina (Khorasan-e Razawi Province.), Meymand (Kohgiluyeva Boyer Ahmad Province), Mormori (Ilam Province), (Benda et al., 2012).

Distribution: Eastern Europe, North Africa, and Middle Eastern Countries.

Meristaspis lateralis (Kolenati, 1856)

New records: 19 from 6 inds. Miniopterus schreibersii, July. 16, 2013, local [5]; 1 \%, 2 , 10 nymphal stage from 1 ind. Rousettus aegyptiacus, July. 6, 2013, local [5]. , 19 from 1 ind. Myotis blythii, July. 6, 2013, local [5].

Previous records: Bishapur cave (Fars Province), Bongaru, Hazarmani Mts. Podonu, Chahar Dahaneh, Zangard (Hormozgan Province), (Benda et al., 2012).

Distribution: Philippines.

\section{Family: Macronyssidae Oudemans, 1936}

Macronyssus granulosus (Kolenati, 1856)

New records: 1 의 1 of from 1 ind. Miniopterus schreibersii, Oct. 27, 2011, local [3].

Remarks: New for Iranian fauna.

Distribution:Europe, Asia.

Hosts: seven bat species (hosts) from Rhinolophidae (1 sp.), Vespertilionidae (3 sp.), Rhinopomatidae (2 sp.), and Pteropodidae (1 sp.) were captured in the caves. All were 50 specimens:

Family: Rhinolophidae:

Rhinolophus hipposideros (Bechstein, 180o)

Locality: Deh Sheikh cave (1\%); Tadovan cave (2ఠ)

Family:Vespertilionidae:

Miniopterus schreibersii (Kuhl, 1817)

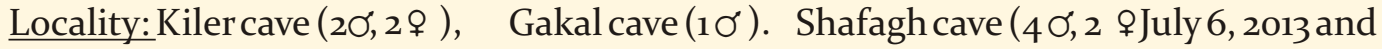
$2 \sigma^{\prime}, 1$ \%, Dec. 8, 2013), Tadovan cave $\left(3 \sigma^{\circ}, 2 \%\right)$.

Myotis blythii (Tomes, 1857),

Locality: Kiler cave: (1ð), Gakal cave: (1ఠ) and Shafagh cave (10) July 6, 2013.

Myotis sp.

Locality: Neyneh cave (19)

Family: Rhinopomatidae:

Rhinopoma muscatellum, Thomas, 1903

Locality: Neyneh cave ( $\left.1 \sigma^{\prime}\right)$; Charkhab cave (9夭', 5 ᄋ)

Rhinopoma microphyllum (Brunnich, 1792)

Locality: Gakal cave (19); Tadovan cave (3 $\sigma^{\prime}, 4$ \%)

Family: Pteropodidae

Rousettus aegyptiacus Geoffroy 1810

Locality: Shafagh cave (10). 


\section{Conclusion:}

Till date very limited studies have been done on ectoparasites of bats in Iran (Benda et al., 2012). Thus, a gap in our knowledge on the subject is existed even if Iran is a vast country with diverse climates having many mountain chains holding caves. The knowledge regarding Bats' ectoparasites help us for understanding the biological, systematic, and phylogenetic aspects of the hosts. In addition, it also helps to clarify the epidemiological aspects of disease transmission among bats. The arthropod ectoparasites of bats usually belongs to the Siphonaptera, Diptera, Hemiptera, Dermaptera, and Acari (ticks and mites) orders, aside from being Nycteribiidae and streblid flies are exclusive to bats (Bertola et al., 2005) and Spinturnicidae, a family of mites (Acari: Mesostigmata) with very high specificity.

Earlier, the investigation of the fauna of the caves of Kohgiluyeh \& Boyer-Ahmad and Fars, in the south-west and south of Iran have ceded us various new and interesting information about different groups of animals such as bats, reptiles, crustaceans, myriapods, spiders, acari and insects (Kashani et al., 2013; Christophoryová et al., 2013; Dashan 2014, Dashan et al., 2014 a\&b, Malek Hosseini et al., 2015 a\&b, Reboleira et al., 2015, Malek Hosseini et al., 2016). In the current study we collected 108 specimens of ectoparasites from seven captured species of bats. Sixteen species of bat ectoparasites were separated and identified. A total of 50 host bats were collected and identified which belonged to 7 species, 5 genera and 4 families. These parasites consisted of 8 species of Nycteribiidae (Diptera), 2 Strelibidae and 6 species of Acari, 2 Ixodidae, 3 Spinturnicidae, and 1 Macronyssidae. Two species of acari are reported as new for the Iranian fauna; Ixodes simplex Neumann, 1906 and Macronyssus granulosus Kolenati, 1856.

In now a days, unfortunately due to high anthropogenic disturbances, the above studied caves have partly been destroyed. Thus, some unique cavernicoles abiding in these habitats could be considered as endangered species. Though, the ceded bat ectoparasites could be enough to big bulk to the subject, but how far it is threatening to the bat populations of the studied caves are yet to be studied.

Acknowledgements:

The authors are thankful to the Dr. Martin Ševčík, from the Department of Zoology, Charles University in Prague, Czech Republic (Slovak Society for Parasitology at Slovak Academy of Sciences, Slovakia), who helped in identification and species confirmation. We would also like to thank Dr. Vahid Akmali, University of Razi, Kermanshah-Iran, and Mr. Alamdar Shafie and his colleagues from Pardis caving club, who helped us in caving. We arealsograteful to the Iranian National Science Foundation (INSF), for the financial support of this study.

\section{References:}

Benda. P., Lučan. R.K., Obuch, J., Reiter, A., Andreas, M., Bačkor, P., Bohnenstengel, T., Eid, E.K., Ševčík, M., Vallo, P. \& Amr, Z.S. (2010): Bats (Mammalia: Chiroptera) of the Eastern Mediterranean and Middle East. Part 8. Bats of Jordan: fauna, ecology, echolocation, ectoparasites. Acta Societatis Zoologicae Bohemoslovenicae, 74: 185-353.

Benda, P., Faizolâhi, K., Andreas, M., Obuch, J., Reiter, A., Ševčík, M., Uhrin, M., Vallo, P. \& Ashrafi, S. (2012): Bats (Mammalia: Chiroptera) of the Eastern Mediterranean and Middle East. Part 10, Bat fauna of Iran. Acta Societatis Zoologicae Bohemoslovenicae, 76:163-582.

Bertola, P.B., Aires, C.C., Favorito, S.E., Gracioli, G., Amaku, M. \& Pinto-De-Rocha, R. (2005): Bat flies (Diptera: Streblidae, Nycteribiidae) parasitic on bats (Mammalia: Chiroptera) at Parque Estadual de Cantareira, Sao Paulo, Brazil: parasitism rates and host-parasite associations. Mem. Instit. Oswaldo Cruz, 100:25-32. 
Christophoryová, J., Dashdamirov, S., Malekhosseini, M.J. \& Sadeghi, S. (2013): First record of the genus Megachernes (Pseudoscorpiones: Chernetidae) from an Iranian cave. Arachnologische Mitteilungen, 46:9-16.

Dashan, M. (2014): Study of the cave fauna of Fars province, Iran. M.Sc. thesis, Shiraz University, Shiraz, Iran.

Dashan, M., Sadeghi, S., Bakhshi, Y. \& Malek Hosseini, M.J. (2014a). First record and redescription of Niptus hololeucus (Faldermann, 1835) from Kangohar Cave (Coleoptera: Ptinidae). Iran. J. Ani. Biosyst.,10(2) 81-85.

Dashan, M., Sadeghi, S. \& Bakhshi, Y. (2014b): First record of the genus Aglenus (Coleoptera: Salpingidaeas) a cave dweller from Iran (Tadovan Cave). Cave Karst Sci., 41:129-131.

Ghaderi, G.H. \& Karimi, 1. (2014): Formation of Angerh Minue Cave in Asmari Karst Complex of Zagros Mountain, Iran. Ambient Sci., 1(1):47-50.

Haitlinger, R. \& Łupicki, D. (2008): Arthropods (Acari, Siphonaptera, Heteroptera, Psocoptera) associated with Nyctalus noctula (Schreber, 1774) (Chiroptera: Vespertilionidae) in Southern Poland. Wiadomooeci Parazytologiczne, 54(2): 123130.

Hůrka, K. (1984): New taxa and new records of Palearctic Nycteribiidae and Streblidae (Diptera: Pupipara). Věstník ČeskoslovenskéSpolečnostiZoologické, 48: 90-101.

Kashani, M.G., Malek Hosseini, M.J. \& Sadeghi, S. (2013): First recorded cave-dwelling terrestrial isopods (Isopoda: Oniscidea) in Iran with a description of a new species. Zootaxa, 3734 (5):591-596.

Kock, D. (1983): Fledermaus-Fliegen in Iran (Insecta: Diptera: Streblidae, Nycteribiidae). Senckenbergiana biologica, 63:167-180.

Krantz, G.W. \& Walter, D.E. (2009): A Manual of Acarology. Texas Tech University Press. Viviii+1807pp

Krasnov, B.R., Shenbrot, G.I., Khokholva, I.S. \& Degen A.A. (2004): Flea species richness and parameters of host body, host geography, and host "milieu". J.Anim. Ecol., 73:1121-1128

Maa, T.C. (1968) On Diptera pupipara from Africa, Part 1.J. Med. Entomol., 5:233-251.

Malek Hosseini, M.J., Grismado, C., Sadeghi, S. \& Bakhshi,Y. (2015a): Description of the first cave dwelling species of the spider genus Trilacuna Tong \& Li from Iran (Araneae: Oonopidae). Zootaxa, 3972 (4):549-561

Malek Hosseini, M.J., Zamani, A. \& Sadeghi, S. (2015b): A survey of cave-dwelling spider fauna of Kohgiluyeh \& Boyer-Ahmad and Fars provinces, Iran (Arachnida: Araneae). Revista Ibérica de Aracnología, 27: 90-94.

Malek Hosseini,M.J., Muilwijk, J., Sadeghi, S. \& Bakhshi, Y. (2016): The Carabid fauna of caves in the southern Zagros Mountains and description of Laemostenus (Antisphodrus) aequalis nov.sp. and Duvalius kileri nov.sp. (Coleoptera: Carabidae) from Kohgiluyeh and Boyer-Ahmad Province, Iran. Entomofauna, 37(10) :185-204

Marshall, A.G. (1982): Ecology of insects ectoparasitic on bats. In: Kunz TH, ed. New York: Plenum, pp. 369-401.

Pomerantzev, B.I. (1959): In: Fauna of USSR volume IV, no. 2. Anastos G, editor. Washington: The American Institute of Biological Sciences; 1959. Ixodid ticks (Ixodidae) (English translation by Elbl A).

Reboleira, A.S., Malek Hosseini, M.J., Sadeghi, S. \& Henrik, E. (2015): Highly disjunct and highly infected millipedes a new cave-dwelling species of Chiraziulus (Diplopoda: Spirostreptida: Cambalidae) from Iran and notes on Laboulbeniales ectoparasites. Europ. J.Taxon., 146:1-18.

Theodor, O. (1967): An illustrated catalogue of the Rothschild Collection of Nycteribiidae in the British Museum (Natural History), with Keys and Short Descriptions for the Identification of Subfamities, Genera, Species and Subspecies. Publication 655. London, British Museum (Natural History), viii+5o6 pp.

Theodor, O. \& Moscona, A. (1954): On bat parasites in Palestine. I. Nycteribiidae, Streblidae, Hemiptera, Siphonaptera. Parasitology, 44:157-245.

Vatandoost, H., Telmadarraiy, Z., Sharifi, M., Moradi, A., Kamali, M. \& Taran, M. (2010): Ectoparasites of lesser mouse eared bat, Myotis blythii from Kermanshah, Iran. Asian Pac. J. Trop. Med.,3:371-373. 